\title{
Implementasi Teori Belajar Humanisme dalam Proses Belajar Mengajar Pendidikan Agama Islam
}

\author{
Aulia Diana Devi \\ Universitas Islam Negeri Sunan Kalijaga Yogyakarta \\ Email:auliadianadevi15@gmail.com
}

\begin{abstract}
The process of educating a child must pay attention to the right theory so that children can absorb and receive lessons, and can apply them well. This study aims to describe the learning theory of humanism in learning Islamic religious education. This study uses a qualitative method with a literature study format. The results of this study indicate that the implementation of humanism learning theory in Islamic education is evidenced by several facts, namely, learning conditions, student conditions, and the existence of activities that support the application of the concept of humanism learning. This implementation can also produce active learning, one of which is the discussion and presentation method, which aims to train the independence and courage of students to express their opinions. Community social activities, which aim to train students' socialization and empathy for their environment. Mentoring and coaching, which aims to shape the character and improve the morals of students, reduce juvenile delinquency, and improve student achievement.
\end{abstract}

Keywords: Humanism, Islamic Religious Education, Theory of Learning.

\begin{abstract}
Abstrak
Proses mendidik seorang anak harus memperhatikan teori yang tepat agar anak dapat menyerap dan menerima pelajaran, serta dapat mengaplikasikannya dengan baik. Penelitian ini bertujuan untuk mendeskripsikan teori belajar humanisme dalam pembelajaran pendidikan agama islam. Penelitian ini menggunakan metode kualitatif dengan format studi literatur. Hasil dari penelitian ini menunjukkan bahwa dalam implementasi teori belajar humanisme pada pembelajaran Ppendidikan Agama Islam dibuktikan dengan beberapa fakta yaitu, kondisi pembelajaran, kondisi siswa, dan adanya kegiatan-kegiatan yang mendukung penerapan konsep pembelajaran humanisme. Implementasi ini juga dapat menghasilkan pembelajaran aktif salah satunya dengan metode diskusi dan presentasi, yang bertujuan untuk melatih kemandirian dan keberaniaan peserta didik untuk mengemukakan pendapatnya. Kegiatan sosial masyarakat, yang bertujuan untuk melatih sosialisasi dan empati siswa terhadap lingkungannya. Pendampingan dan pembinaan, yang bertujuan untuk membentuk karakter dan memperbaiki akhlak peserta didik, mengurangi kenakalan remaja, serta meningkatkan prestasi siswa.
\end{abstract}

Kata Kunci: Humanisme, Pendidikan Agama Islam, Teori Belajar. 


\section{A. Pendahuluan}

Setiap individual berhak dalam upaya pengembangan diri serta pengaktualisasiannya. Hal ini hanya dapat dilakukan melalui proses pendidikan (Endang Komara 2014, hlm. 2). Agar tetap survive dalam menghadapi dan melestarikan alam semesta manusia membutuhkan pendidikan (Abudin Nata 2014, hlm. 67). Jadi, pendidikan merupakan salah satu upaya mencapai tujuan yang secara runtut mengarah pada perbaikan tingkah laku menuju kedewasaan anak didik (Sumantri dan Ahmad 2019, hlm. 1).

Berbicara mengenai proses mendidik siswa atau anak, tentu haruslah bersandar pada sebuah teori, ini bertujuan agar siswa dapat menyerap dan menerima pelajaran dengan baik, dan bisa mengaplikasikannya dengan baik pula. Akan tetapi, memilih sebuah teori atau pendekatan sesuai kebutuhan, usia, pola pikir siswa tersebut (Mahrus dan Itqan 2020, hlm. 75). Teori adalah suatu pendapat yang didasarkan pada penelitian dan penemuan yang didukung oleh data dan argumentasi (El Raiz 2012, hlm. 667). Teori Belajar merupakan upaya untuk mendeskripsikan bagaimana manusia belajar, sehingga membantu kita semua memahami proses inhern yang kompleks dari belajar. Cahyo berpendapat bahwa teori belajar dapat diartikan sebagai konsep-konsep dan prinsip-prinsip belajar yang bersifat teoritis dan telah teruji kebenarannya melalui eksperimen (Dra.Tutik Rachmawati, M.Pd dkk 2015, hlm. 36).

Maka untuk mencapai hal tersebut, guru memegang peran yang sangat penting pada kegiatan belajar mengajar, guru bertanggung jawab mengarahkan anak didiknya dalam hal penugasan dan penerapan ilmu dalam kehidupan mereka, menanamkan dan memberikan teladan yang baik terhadap anak didiknya kaitannya dengan Pendidikan Agama Islam. Tujuan dari Pendidikan Agama Islam sendiri adalah untuk mengembangkan potensi peserta didik (manusia) secara maksimal, sehingga pendidikan mampu berfungsi sebagai proses memanusiakan manusia (humanisasi). Dengan 
memberikan kebebasan gerak pada peserta didik untuk mengembangkan potensi yang dimiliki secara optimal, harapan Pendidikan Agama Islam dapat kembali mampu menjalankan fungsinya sebagai sarana pemberdayaan dan humanisasi. Namun, Pendidikan Agama Islam di sekolah pada umumnya masih pada tataran penyampaian materi saja. Hal tersebut terlihat dari metode yang digunakan oleh guru masih konvensional sehingga terkesan peserta didik pasif dalam pembelajaran.

Oleh karena itu, diperlukan sebuah pendekatan alternatif supaya pembelajaran PAI dapat lebih bermakna. Pendekatan tersebut dikenal dengan humanisme. Dalam pendekatan humanisme, guru tidak sekadar melakukan transfer of knowledge atau transfer of values, akan tetapi mengharuskan guru mempersiapkan peserta didiknya dengan penuh kasih sayang agar menjadi individu yang saleh dalam arti memiliki tanggung jawab, religius, dan peka terhadap lingkungan hidup. Dengan adanya pendekatan humanisme diharapkan siswa memahami potensi diri, mengembangkannya secara positif dan meminimalisir potensi negatif dalam dirinya. Menjunjung tinggi rasa tanggung jawab terhadap sesama, bisa saling menghormati dan menjunjung nilai-nilai pluralisme.

Berdasarkan uraian di atas peneliti termotivasi untuk mengetahui lebih jauh lagi tentang teori belajar humanisme serta penerapannya dalam pembelajaran, khususnya Pendidikan Agama Islam. Walaupun guru memiliki teori yang baik akan tetapi jika tidak didukung dengan metode yang baik pula maka mungkin hasilnya tidak akan sesuai dengan apa yang diharapkan.

\section{B. Metode}

Analisis metode dalam jurnal ini menggunakan library research dengan menggunakan pendekatan filosofis (mengkaji implementasi teori belajar humanisme dalam pembelajaran pendidikan agama islam). Teknik pengmpulan data yang digunakan dengan teknik dokumentasi yaitu mengumpulkan data dari sumber buku-buku yang ada di perpustakaan, 
artikel-artikel yang berhubungan dengan tulisan-tulisan terkait dengan penelitian, serta dikumpulkan dan diambil dan diintisarikan serta dikaitkan dengan objek kajian (Joko Subagyo 1991, hlm. 109).

Analisis data dilakukan dengan cara menelaah berbagai literature dari data dokumentasi terhadap berbagai data-data dari hasil penelitian terkait dengan obyek penelitian artikel. Taham petama dilakukan dengan memganalisis dan mengidentifikasi seperti apa masalah yang dikaji. Tahap kedua mengkaji sebagai sumber dan dokumentasi yang perlu dicari solusinya atas persoalan masalahnya. Tahapan ketiga adalah menarik kesimpulan atas kajian masalah yang telah ditulis.

\section{Hasil dan Pembahasan}

\section{Teori Belajar Humanisme}

Teori humanisme muncul pada pertengahan abad 20 sebagai reaksi terhadap teori psikodinamik dan behavioristik. Para teoritikus humanisme meyakini bahwa tingkah laku manusia tidak dapat dijelaskan sebagai hasil dari konflik-konflik yang tidak disadari maupun sebagai hasil (conditioning) yang sederhana. Teori ini berfokus pada pentingnya pengalaman disadari yang bersifat subyektif dan self-direction (Desmita 2012, hlm. 45).

Humanisme berasal dari kata latin humanus berarti sifat manusiawi atau sesuai dengan kodrat manusia. Adapun secara terminologi, humanisme berarti martabat dan nilai dari setiap manusia, serta upaya untuk meningkatkan kemampuan-kemampuan alamiah yang dimilikinya baik fisik maupun non fisik secara maksimal. Dalam psikologi, humanisme juga dikenal dengan sebutan humanisme (Djayadin dan Fathurrahman 2020, hlm. 31). Di sisi lain humanisme berarti minat terhadap nilai-nilai kemanusiaan yang bersifat ketuhanan. Sedangkan humanisme dalam tataran akademik tertuju pada pengetahuan tentang budaya manusia, seperti studi-studi klasik mengenai kebudayaan Yunani dan Roma (Qodir 2017, hlm. 191). 
Humanisme memandang manusia sebagai manusia, artinya manusia adalah makhluk hidup ciptaan Tuhan dengan fitrah-fitrah tertentu. Ciri khas teori humanisme adalah berusaha untuk mengamati perilaku seseorang dari sudut si pelaku dan bukan si pengamat. Sebagai makhluk hidup, ia harus melangsungkan, mempertahankan, dan mengembangkan, hidupnya dengan potensipotensi yang dimilikinya (Baharuddin, Moh Makin 2007, hlm. 22). Jadi humanisme merupakan aktivitas jasmani dan rohani guna memaksimalkan proses perkembangan. Atau sebagai upaya menguasai khazanah ilmu pengetahuan sebagai rangkaian pembentukan kepribadian secara menyeluruh (Fajri Ismail 2014, hlm. 25).

Teori Humanisme juga memiliki beberapa prinsip di antaranya yaitu: (1) merumuskan tujuan belajar yang jelas, mengusahakan partisipasi aktif siswa melalui kontrak belajar yang bersifat jelas , jujur dan positif, (2) mendorong siswa untuk mengembangkan kesanggupan siswa untuk belajaratas inisiatif sendiri, (3) mendorong siswa untuk peka berpikir kritis, memaknai proses pembelajaransecara mandiri, (4) siswa di dorong untuk bebas mengemukakan pendapat, memilih pilihannyasendiri, melakukkan apa yang diinginkan dan menanggung resiko dariperilakuyang ditunjukkan, (5) guru menerima siswa apa adanya, berusaha memahami jalan pikiran siswa,tidak menilai secara normatif tetapi mendorong siswa untuk bertanggungjawabatas segala resiko perbuatan atau proses belajarnya, (6) memberikan kesempatan murid untuk maju sesuai dengan kecepatannya, (7) evaluasi diberikan secara individual berdasarkan perolehan prestasi siswa.

Namun, teori Humanisme terlihat sulit diterapkan dalam konteks yang lebih praktis. Teori ini dianggap lebih dekat dengan bidang filsafat dan teori kepribadian daripada bidang pendidikan, sehingga sukar menerjemahkannya ke dalam langkah-langkah yang lebih konkret dan praktis, namun karena sifatnya yang ideal, yaitu memanusiakan manusia, oleh karena itu teori humanisme mampu memberikan arah terhadap semua komponen pembelajaran untuk mendukung tercapainya tujuan tersebut. 
Abraham H. Maslow sebagai salah satu tokoh dalam teori belajar humanisme, Ia mengangkat teori tentang motivasi dan teori mengenai hirarki kebutuhan (Endang Komara 2014, hlm. 3). Kebutuhan dibagi menjadi 5 tingkatan, yaitu kebutuhan jasmaniah (physiological needs), kebutuhan akan keselamatan dan rasa aman (safety and security needs), kebutuhan untuk diterima (sosial needs), kebutuhan akan harga diri (self-esteem) dan kebutuhan aktualisasi diri (self actualization) (Iskandar 2016, hlm. 27). Maslow beranggapan bahwa pemikiran kesehatan rohani didasarkan pada pemenuhan kebutuhan alami manusia guna pengaktualisasian diri. Aplikasinya dalam pembelajaran menuntut guru untuk memerhatikan pemenuhan hierarki kebutuhan-kebutuhan tersebut, terutama pada individu siswa (Mahrus dan Itqan 2020, hlm. 80-81).

Selanjutnya, Arthur W. Combs juga sebagai salah satu tokoh pada teori ini dengan konsep teorinya yaitu meaning (makna atau arti). Proses belajar pada siswa akan benar-benar terjadi apabila sesuatu yang dipelajari memiliki arti bagi individu siswa yang bersangkutan (Yuliandri 2017, hlm. 104). Menurutnya, aktivitas belajar melibatkan empat hal, yaitu perasaan, persepsi, keyakinan dan tujuan yang sifatnya inner (dari dalam). Comb berpendapat bahwa dalam proses belajar harus mempunyai arti bagi individu, guru tidak bisa memaksakan materi yang tidak disukai atau tidak relevan dengan kehidupan siswa.

Penerapan teori humanisme pada kegiatan belajar hendaknya pendidik menuntun peserta didik berpikir induktif, mengutamakan praktik serta menekankan pentingnya partisipasi peserta didik dalam pembelajaran (Perni 2018, hlm. 7-8). Teori ini juga amat mementingkan faktor pengalaman dan keterlibatan siswa secara aktif dalam belajar.

\section{Pembelajaran Pendidikan Agama Islam}

Pada hakikatnya pembelajaran adalah suatu proses belajar mengajar dimana siswa sebagai pusat dari kegiatan pembelajaran. Hal ini dimaksudkan 
agar membentuk watak, peradaban, dan meningkatkan mutu kehidupan peserta didik (Hamruni 2010, hlm. 39). Proses pembelajaran pada hakikatnya merupakan pelayanan yang khusus diperuntukkan bagi siswa. Proses pembelajaran dalam Pendidikan Agama Islam, sebenarnya menggunakan prinsip-prinsip umum proses pembelajaran. Komponen-komponen yang terlihat umumnya sama, yaitu mencakup tujuan, bahan, metode, alat, dan evaluasi (Tohirin 2005, hlm. 17).

Pendidikan merupakan upaya yang direncanakan untuk mempengaruhi orang lain baik individu, kelompok, atau masyarakat sehingga mereka melakukan apa yang diharapkan oleh pelaku pendidikan (Nasution 2003, hlm. 16). Hakikat Pendidikan Agama Islam adalah menyiapkan peserta didik untuk mengenal, memahami, menghayati, hingga mengimani, bertakwa, dan berakhlak mulia dalam mengamalkan ajaran agama Islam dari sumber utamanya kitab suci Al-Qur'an dan Al hadist, melalui kegiatan bimbingan, pengajaran, latihan, serta penggunan pengalaman (Abdul. Majid 2012, hlm. 11). Tujuan pendidikan agama Islam yaitu untuk membentuk manusia yang muttaqin (Baharuddin 2010, hlm. 192). Dapat disimpulkan bahwa Pendidikan Agama Islam ialah Upaya sadar dan terencana yang dilakukan oleh individu untuk mengenal, memahami, menghayati, hingga mengimani, bertakwa, dan berakhlak mulia dalam mempelajari dan mengamalkan Agama Islam itu sendiri sesuai dengan pedomannya yaitu berpegang teguh pada Al-Qur'an dan Al-Hadist.

Pendidikan Agama Islam merupakan usaha sadar dan terencana untuk menyiapkan siswa dalam meyakini, memahami, menghayati, dan mengamalkan ajaran Islam melalui kegiatan bimbingan, pengajaran dan atau latihan" (Nazarudin 2007, hlm. 1). Pada hakikatnya Pendidikan Agama Islam merupakan sebuah proses yang dalam pengembangannya dimaksudkan sebagai rumpun mata pelajaran yang diajarkan di sekolah maupun perguruan tinggi. Dengan demikian, Pendidikan Agama Islam dapat dimaknai dalam dua 
pengertian, yakni sebagai sebuah proses penanaman ajaran agama Islam dan sebagai bahan kajian yang menjadi materi dari proses pendidikan itu sendiri.

Pendidikan Agama Islam diberikan dengan mengikuti tuntunan bahwa agama dianjurkan kepada manusia dengan visi untuk mewujudkan manusia yang bertakwa kepada Allah SWT dan berakhlak mulia, serta bertujuan untuk menghasilkan manusia yang jujur, adil, berbudi pekerti, etis, saling menghargai, disiplin, harmonis, dan produktif, baik personal maupun sosial (Nazarudin 2007, hlm. 95). Adapun tujuan Pendidikan Agama Islam di tingkat sekolah menengah atas adalah sebagai berikut (Nazarudin 2007, hlm. 96):

a. Menumbuhkembangkan akidah melalui pemberian, pemupukan, dan pengembangan pengetahuan, penghayatan, pengamalan, pembiasaan, serta pengalaman peserta didik tentang Agama Islam sehingga menjadi manusia muslim yang terus berkembang keimanan dan ketakwaannya kepada Allah SWT.

b. Mewujudkan manusia Indonesia yang taat beragama dan berakhlak mulia yaitu manusia yang berpengetahuan, rajin beribadah, cerdas, produktif, jujur, adil, berdisiplin, toleransi (tasamuh), menjaga keharmonisan secara personal dan sosial serta mengembangkan budaya agama dalam komunitas sekolah.

Proses pelaksanaan teori belajar humanistik dalam pembelajaran Pendidikan Agama Islam disini adalah proses pembelajaran yang digunakanan guru yang berkaian dengan kemampuan, stimulus yang terkontrol yang dapat diterima dan di respon oleh siswa. Secara umum siswa dapat melaksanakan proses pembelajaran dengan baik. Siswa dapat menjalankan kegiatan sesuai dengan RPP yaitu mengamati, menanya, eksperimen atau eksplor, asosiasi, komunikasi dan refleksi. Dalam proses pembelajaran di kelas, guru harus memperhatikan situasi dan kondisi kelas maupun siswa yang ada di dalamnya agar pembelajaran berlangsung dengan baik. 
Proses belajar dianggap berhasil jika siswa dapat memahami lingkungannya dan dirinya sendiri. Dalam proses belajarnya siswa harus berusaha agar ia mampu mencapai aktualisasi diri dengan sebaik-baiknya. Setiap siswa pasti memiliki kecepatan belajar yang berbeda-beda sehingga keberhasilan belajar akan tercapai apabila pembelajar dapat memahami diri dan lingkungannya. Hal ini karena setiap manusia adalah unik dan tugas pendidik adalah membantu mengenali sisi unik tersebut serta mewujudkan potensi yang dimiliki oleh siswa (Jamil Suprihatiningrum 2013, hlm. 31-32).

\section{Implementasi Teori Belajar Humanisme Dalam Pembelajaran Pendidikan Agama Islam}

Penerapan teori humanisme lebih menunjuk pada ruh atau spirit selama proses pembelajaran yang mewarnai metode-metode yang diterapkan. Peran guru dalam pembelajaran humanisme adalah menjadi fasilitator bagi para peserta didik dan guru memberikan motivasi, kesadaran mengenai makna belajar dalam kehidupan peserta didik. Guru memfasilitasi pengalaman belajar kepada peserta didik dan mendampingi peserta didik untuk memperoleh tujuan pembelajaran. Peserta didik berperan sebagai pelaku utama (student center) yang memaknai proses pengalaman belajarnya sendiri. Diharapkan peserta didik memahami potensi diri, mengembangkan potensi dirinya secara positif dan meminimalkan potensi diri yang bersifat negatif.

Teori belajar humanisme dirasa penting untuk diterapkan dalam proses belajar mengajar disekolah, dan telah sedikit banyak diterapkan oleh pendidik dalam mengajar baik secara langsung atau terencana maupun secara tidak langsung atau mengalir begitu saja, karena sebenarnya pada dasarnya setiap pembelajaran menganut aliran teori belajar humanisme. Konsep belajar dengan teori humanisme efektif diterapkan untuk pembelajaran dengan materi-materi elajaran yang bersifat membentuk kepribadian, hati nurani, perubahan sikap, dan analisis terhadap fenomena sosial, salah satunya adalah 
mata pelajaran Pendididikan Agama Islam, karena agama merupakan salah satu pondasi pembentukan kepribadian dan akhlak manusia.

Berkaitan dengan hal tersebut, sudah banyak sekolah yang berusaha menerapkan sistem pembelajaran dengan mengacu pada konsep humanisme, khususnya pada mata pelajaran Pendidikan Agama Islam. Hal ini dibuktikan dengan beberapa fakta sebagai berikut:

a. Kondisi di kelas selama pelajaran.

Sebelum pelajaran dimulai, siswa diminta mengamati lingkungan tempat duduknya apakah sudah bebas dari sampah-sampah kertas dan lainnya, jika masih terdapat sampah, peserta didik memungutnya dan membuangnya ke tempat sampah, sehingga kondisi lingkungan belajar menjadi bersih dan nyaman. Setelah itu pelajaran diawali dengan bersholawat, membaca asmaul husna, kemudian doa-doa sehari-hari.

Hal ini dilakukan untuk merangsang peserta didik dan untuk memperkuat hafalan peserta didik baik surat-surat dalam Al-Qur'an, doa sehari-hari, maupun sholawat-sholawat nabi, agar siswa terbiasa dengan bersholawat.

b. Memberikan ruang bebas kepada peserta didik.

Ini bertujuan agar siswa mampu meningkatkan pemahamannya terhadap materi yang disampaikan oleh guru. Pada proses ini siswa diajarkan untuk berani berpendapat, percaya diri, dan tanggung jawab. Anak juga dapat mengeksplor lebih dalam tentang materi yang disampaikan. Seperti halnya model pembelajaran active learning, yang memiliki 4 semboyan, yaitu apa yang saya dengar dengan mudah saya lupakan, apa yang saya dengar dan saya lihat akan saya ingat sedikit atau sebentar, apa yang saya dengar, lihat, dan tanyakan atau diskusikan, dan laksanakan, maka saya memperoleh pengetahuan dan ketrampilan, dan ketika saya bisa mengajari orang lain, berarti saya menguasai. 
c. Kegiatan-kegiatan yang mendukung.

Dalam pelaksanaan pembelajaran humanisme perlu adanya kegiatan yang nyata. Seperti lembaga pendidikan yang berusaha untuk mewujudkan kegiatan-kegiatan yang mendukung penerapan konsep pembelajaran humanisme. Bukan hanya kegiatan-kegiatan tersebut saja siswa-siswa yang tidak mematuhi peraturan seperti halnya membolos, terlambat, berambut panjang bagi laki-laki dan pelanggaran-pelanggaran lainnya juga diberikan peringatan dan hukuman. Sejatinya reward dan panishment itu dirasa penting dalam suatu pembelajaran, reward dan panishment melatih siswa tentang tanggung jawab dan kedisiplinan, memotivasi siswa.

Akan tetapi, bukan hanya pendisiplinan siswa saja, akan tetapi ketika pembelajaran berlangsung, Untuk memancing agar peserta didik aktif, guru memberikan penghargaan kepada setiap siswa yang berani menjawab pertanyaan yang diajukan dengan memberikan tambahan point, siswa akan berebut untuk menjawab pertanyaan yang diajukan. Dengan demikian melatih keberanian siswa untuk berpendapat dan rasa percaya dirinya akan terus meningkat. Selain menumbuhkan semangat belajar peserta didik didalam kelas, peserta didik juga diajarkan kemandirian dengan model pembelajaran yang mengacu pada guru sebagai fasilitator.

\section{Kesimpulan}

Penerapan teori belajar humanisme dalam pembelajaran PAI harus memperhatikan beberapa fakta, seperti kondisi di dalam kelas selama pelajaran, memberikan ruang bebas kepada peserta didik dalam pembelajaran, dan adanya kegiatan-kegiatan yang mendukung penerapan konsep pembelajaran humanisme. Implementasi ini juga dapat menghasilkan pembelajaran aktif salah satunya dengan metode diskusi dan presentasi, yang bertujuan untuk melatih kemandirian dan keberaniaan peserta didik untuk mengemukakan pendapatnya. Kegiatan sosial masyarakat, yang bertujuan 
untuk melatih sosialisasi dan empati siswa terhadap lingkungannya. Pendampingan dan pembinaan, yang bertujuan untuk membentuk karakter dan memperbaiki akhlak peserta didik, mengurangi kenakalan remaja, serta meningkatkan prestasi siswa.

\section{DAFTAR PUSTAKA}

Abdul. Majid. 2012. Belajar dan Pembelajaran Pendidikan Agama Islam. Bandung: PT Remaja Rosda Karya.

Abudin Nata. 2014. Sejarah Pendidikan Islam. Jakarta: Kencana.

Baharuddin. 2010. Pendidikan Psikologi Pendidikan. Yogyakarta: Ar-Ruzz Media.

Baharuddin, Moh Makin. 2007. Pendidikan Humanistik: Konsep, Teori, dan Aplikasi Praksis dalam Dunia Pendidikan. Yogyakarta: Ar-Ruzz Media.

Desmita. 2012. Psikologi Perkembangan Peserta Didik Panduan bagi Orang Tua dan Guru dalam Memahami Psikologi Anak Usia SD, SMP, dan SMA. Bandung: PT Remaja Rosda Karya.

Djayadin, Chairunnisa, dan Fathurrahman Fathurrahman. 2020. "Teori Humanisme sebagai Dasar Etika Religius (Perspektif Ibnu Athā'illah AlSakandarī)." Al-Izzah: Jurnal Hasil-Hasil Penelitian 15 (1). https://doi.org/10.31332/ai.v0i0.1788.

Dra.Tutik Rachmawati, M.Pd dkk. 2015. Teori belajar dan Proses Pembelajaran yang mendidik. Yogyakarta: Gava Media.

El Raiz. 2012. Kamus Ilmiah Populer. Yogyakarta: Pustaka Belajar.

Endang Komara. 2014. Belajar dan Pembelajaran Interaktif. Bandung: PT Refrika Aditama.

Fajri Ismail. 2014. Evaluasi Pendidikan. Palembang: Tunas Gemilang Press.

Hamruni. 2010. Strategi Pembelajaran. Yogyakarta: Fakultas Tarbiyah dan Keguruan UIN Sunan Kalijaga.

Iskandar. 2016. "Implementasi Teori Hirarki Kebutuhan Abraham Maslow Terhadap Peningkatan Kinerja Pustakawan" 4 (1).

Jamil Suprihatiningrum. 2013. Strategi Pembelajaran: Teori dan Aplikasi. Yogyakarta: Ar-Ruzz Media.

Joko Subagyo. 1991. Metode Penelitian dan Praktek. Jakarta: Rhineka Cipta.

Mahrus, dan Zubdatul Itqan. 2020. "Implikasi teori humanistik dan kecerdasan ganda dalam desain pembelajaran PAI." PIWULANG: Jurnal Pendidikan Agama Islam 3 (1): 74-91.

Nasution. 2003. Metode Naturalistik - Kualitatif. Bandung: PT Tarsito.

Nazarudin. 2007. Manajemen Pembelajaran Implementasi Konsep, Karakteristik dan Metodologi Pendidikan Agama Islam di Sekolah Umum. Yogyakarta: Teras. 
Perni, Ni Nyoman. 2018. "Penerapan Teori Belajar Humanistik Dalam Pembelajaran." Adi Widya: Jurnal Pendidikan Dasar 3 (1). https://doi.org/10.25078/aw.v3i2.889.

Qodir, Abdul. 2017. "Teori Belajar Humanistik Dalam Meningkatkan Prestasi Belajar Siswa." Jurnal Pedagogik 04 (02).

Sumantri, Budi Agus, dan Nurul Ahmad. 2019. "Teori Belajar Humanistik Dan Implikasinya Terhadap Pembelajaran Pendidikan Agama Islam." FONDATIA 3 (2): 1-18. https://doi.org/10.36088/fondatia.v3i2.216.

Tohirin. 2005. Psikologi Pembelajaran Pendidikan Agama Islam. Jakarta: Rajawali Pers.

Yuliandri, Miki. 2017. "Pembelajaran Inovatif di Sekolah Berdasarkan Paradigma Teori Belajar Humanistik." Journal of Moral and Civic Education 1 (2). https://doi.org/10.24036/8851412020171264. 
